\title{
O humor racista midiático: as políticas da dor e do ódio como desenho risível do corpo negro
}

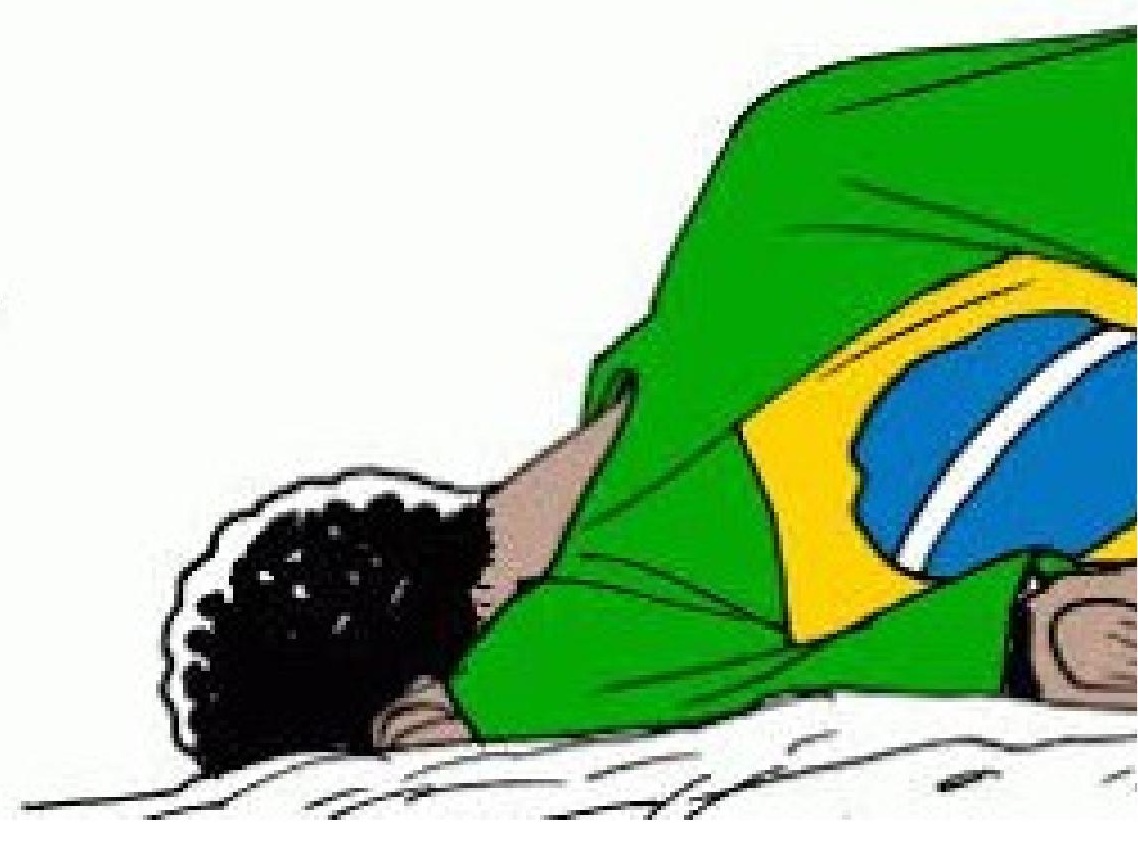

Carlos Latuff, charge, 2019 fotografia (detalhe).

\section{Marina Caminha}

Doutora em Comunicação Social pela Universidade Federal Fluminense (UFF). Pós-doutoranda vinculada ao Programa de Pós-graduação em Cinema da UFF. Bolsista Faperj. ninacaminha@gmail.com 


\section{O humor racista midiático: as políticas da dor e do ódio como desenho risível do corpo negro ${ }^{1}$}

Racist media humour: the politics of pain and hate as laughable drawing of the Black body

\section{Marina Caminha}

\section{RESUMO}

Proponho neste artigo analisar o humor racista midiático para tensionar os sentidos atribuídos à palavra "brincadeira" como algo sem intenção ofensiva quando associada à comicidade. Interessa-me discutir os desenhos risíveis do corpo negro como encarceramento, situando-o numa determinada posição social, cultural e política. Desenvolverei esse argumento relacionando três perspectivas: a comicidade racista, as disputas de sentido do riso como brincadeira e como as emoções circulam essa gargalhada, nas figuras da dor e do ódio para desenhar o corpo negro como feio, animal e criminoso.

PALAVRAS-CHAVE: riso; racismo; emoções.

\begin{abstract}
In this article, I intend to analyze the racist media humor in order to tension the meanings attributed to the word "joke" as something without offensive intent when associated with comic. I am interested in discussing the laughable drawings of the black body as incarceration, placing it in a certain social, cultural and political position. I will develop this argument by linking three perspectives: racist comedy, disputes about the meaning of laughter as a joke and how emotions circulate this laughter, in the figures of pain and hatred to draw the black body as ugly, animal and criminal.
\end{abstract}

KEYWORDS: laugh; racism; emotions.

Nos fins de 1959, foi criado um boato de que em 1960 o negro iria virar macaco. Nesse período foi composto um frevo em tom cômico chamado "Operação macaco" (Sebastião Lopes e Nelson Ferreira) com os seguintes versos: "Dizem que em 60/ nego vai virar macaco/ ora, vejam só, que grande confusão/ se é verdade esta operação macaco/ penca de banana vai custar um milhão". No mesmo período, uma paródia popular e sem autoria da música "Pisa na fulô" (de João do Vale, Ernesto Pires e Silveira Júnior) continha as frases: "pisa na fulô/ escorrega num buraco/ no ano de $60 /$ nego vai virar macaco". ${ }^{2}$

\footnotetext{
${ }^{1}$ Este artigo é parte de uma pesquisa de pós-doutoramento, financiada pela Faperj, voltada para a comicidade no audiovisual em suas dimensões colonizadoras e emocionais.

${ }^{2}$ Tive acesso a essa paródia através dos relatos de minha mãe sobre a época em que ela estudava no Colégio Nossa Senhora de Lourdes (Palmares/PE). Durante esse período os alunos utilizaram essa música como ferramenta para difamar e desqualificar o professor negro que eles tinham em sala de aula. É paradoxal a analogia entre a paródia criada e a música original, composta por um compositor negro e nordestino que, através de várias outras canções, ressaltou a vivência de sua cor e sua origem - entre elas, "Pra mim não",
} 
Durante a década de 1980, em um esquete cômico exibido no programa "Os Trapalhões" (TV Globo), Didi (Renato Aragão) voava - parodiando o personagem Super-homem. Os personagens que assistiam àquela imagem perguntavam o que era aquilo que estava sendo visto:

Personagem 1 (homem branco): É um pássaro?

Personagem 2 (mulher branca): É um avião?

Personagem 3 (homem branco): É um foguete?

Mussum (debochando): É um palhaço voandis!

Didi: Palhaço é a veia, Crioulo!

Dedé: Um Sputnik?

Personagem 4 (homem branco): É o Super-homem!

Mussum: É uma arara cheia de mé!

Didi: Arara é a sua mãe, Crioulo! Kunta Kinte é o que você é! É urubu e não 'avoa'!3

Em outubro de 2012, o humorista Danilo Gentilli, no Twitter, interpelou o empresário Thiago Luís Ribeiro: “Quantas bananas você quer para deixar esta história para lá?". O questionamento do humorista aconteceu em função de várias postagens do empresário, na mesma rede social, evidenciando o racismo contido nas narrativas cômicas de Gentilli. Em 24 de abril de 2014, o humorista foi inocentado no processo por injúria racial aberto por Thiago Luís Ribeiro no Tribunal de Justiça do Estado de São Paulo. ${ }^{4}$

Iniciei este texto citando exemplos de narrativas cômicas constituídas em diferentes tempos históricos e suportes midiáticos. O ponto comum em todas elas é a significação do corpo negro como análogo ao animal macaco ou urubu (este último no caso de "Os Trapalhões"). Adilson Moreira ${ }^{5}$ diz que a vinculação entre o corpo negro e um animal irracional produz um efeito identitário e se constitui como um projeto, tornando a ideia de ser negro como ser incivilizado.

Pensar a incivilidade como característica semântica direcionada ao corpo negro significa, em outras palavras, que o desenho projetado nesse corpo o coloca em posição de desigualdade em relação ao corpo branco, pois é forjado em uma sociedade que privilegia a razão e a ciência como instâncias centrais à organização da vida cotidiana. Nesse sentido, o corpo branco passa a ser desenhado como o corpo capaz de orientar nossas práticas políticas, culturais e sociais. Assim, é também no espaço do riso que o corpo negro incorpora sentidos que o encarcera, tornando-se exemplo de um projeto colonizador. ${ }^{6}$

que contém os versos: "Dizem que acabou a escravidão/ mais pra mim não/ eu conheço um dito assim/ todos nós somos irmãos/ e o sol nasceu pra todos/ pra mim não, pra mim não". VALE, João do. "Pra mim não". A voz do povo, Philips, 1965.

3 GARCIA, Roosevelt. O humor politicamente incorreto dos Trapalhões. 2017. Disponível em $<$ https://vejasp.abril.com.br/blog/memoria/o-humor-politicamente-incorreto-dos-trapalhoes/>. Acesso em 9 out. 2019.

4 Ver Tribunal de Justiça de São Paulo. Processo n. 0104664-15.2012.8.26.0050, Órgão Julgador: $10^{\circ}$ Vara Criminal, Juiz: Marcelo Matias Pereira, 24 abr. 2014. Disponível em <https://www.conjur.com.br/dl/gentilibanana-macaco.pdf>. Acesso em 4 abr. 2020.

${ }^{5}$ Cf. MOREIRA, Adilson. Racismo recreativo. São Paulo: Sueli Carneiro/Pólen, 2019.

${ }^{6}$ A perspectiva colonizadora aqui discutida se vincula ao conceito de situações coloniais, proposto por Ramón Grosfoguel como a “opressão/exploração cultural, política, sexual e económica de grupos étnicos/racializados subordinados por parte de grupos étnico-raciais dominantes, com ou sem a existência 
Moreira e José Dagoberto Fonseca ${ }^{7}$ apontam algumas das principais temáticas encontradas em piadas racistas, entre elas a feiura, a criminalização e a animalização. Neste texto proponho pensar como essas temáticas ecoam traços de um imaginário histórico do riso no audiovisual brasileiro e permanecem como tessituras cômicas nas redes sociais, direcionado para a produção simbólica de corpos negros como alvos risíveis. Parto da hipótese de que a narrativa cômica é entendida como um marcador corporal político, um projeto sobre a maneira como nossos corpos são orientados a sentir o outro através das emoções vinculadas ao ato de rir. Dessa forma, tais temas são pensados como matrizes emocionais que se constituem como operadores narrativos de uma lógica cômica hegemônica de desenhar e inferiorizar corpos negros.

Outro pressuposto é de que a percepção da centralidade de temáticas abordadas não invalida a presença de outras vinculações simbólicas contidas no humor racista. Em muitas narrativas o diálogo entre essas marcas e outras amarrações é uma estratégia para fixar e potencializar a desumanização como desenho do corpo negro. A identificação de Mussum como Kunta Kinte, pelo personagem Didi, em diálogo com a palavra urubu emerge desse processo. Kunta Kinte é o nome dado a um escravo levado forçosamente da África para os Estados Unidos. Uma história contada no romance Raízes: a saga de uma família americana, de Alex Haley, e que foi transformada pela rede televisiva americana ABC em minissérie, sendo transmitida pela TV Globo, em 1979. No esquete cômico, o termo Kunta Kinte foi utilizado para ressaltar, por intermédio dos usos de uma memória televisual, a condição de escravo como desenho do corpo de Mussum. ${ }^{8}$

Como em outras práticas racistas, o humor racista envolve uma difamação desenhada no corpo negro - marcas na superfície que se espelham nos traços fenotípicos do ser negro. Entretanto, por estar alinhado ao campo da comicidade/brincadeira, apresenta como diferença o silenciamento de uma intenção violenta como operação simbólica. Moreira vai dizer que a imagem de recreação contida no riso racista serve como escudo protetor da "imagem social de pessoas brancas" ${ }^{\prime \prime}$, pois encampa a ideia da inexistência de uma ação racista através do riso. Desse modo, narrativas cômicas racistas tornam-se uma máscara conveniente de projeção de uma política colonizadora que faz da raça um dos critérios centrais de discriminação.

\footnotetext{
de administrações coloniais". Para ele os processos de hierarquização étnicos, raciais, de gênero, sexuais e de classe operam como um conjunto de hierarquias enredadas que estruturam o sistema-mundo colonial/moderno. Nesse sentido, as situações coloniais também operam na produção de subjetividades e de conhecimento como partes estruturantes desse sistema de poder. Cf. GROSFOGUEL, Ramón. Para descolonizar os estudos de economia política e os estudos pós-coloniais: transmodernidade, pensamento de fronteira e colonialidade global. Revista Crítica de Ciências Sociais, n. 80, Coimbra, 2008, p. 126. Disponível em <https://doi.org/10.4000/rccs.697>. Acesso em 10 maio 2020.

${ }^{7}$ A hiperssexualização é outra temática bastante difundida em piadas racistas, como salienta José Dagoberto Fonseca. A escolha por não trabalhar com essa questão nesse artigo diz respeito ao entendimento de que há um debate interseccional, vinculado à mulher e ao feminicídio, que demanda um tempo maior de escrita $\mathrm{e}$ pesquisa para não se correr o risco de despolitizar uma luta importante e necessária. MOREIRA, Adilson, op. cit., e FONSECA, José Dagoberto. Você conhece aquela?: a piada, o riso e o racismo à brasileira. São Paulo: Selo Negro, 2012.

${ }^{8}$ Ver A luta dos negros no horário nobre. TV Pesquisa. Disponível em <https://www.tv-pesquisa.com.pucrio.br/> Acesso em 10 jul. 2020.

${ }_{9}^{9}$ MOREIRA, Adilson, op. cit., p. 31.
} 
O investimento simbólico em desumanizar e criminalizar o corpo negro corrobora para a instrumentalização de ações violentas direcionadas a esse corpo, justificando um aparato legal de punição e apagamento de vidas negras. Segundo a recente pesquisa apresentada pelo Instituto de Pesquisa Econômica Aplicada (Ipea) e pelo Fórum Brasileiro de Segurança, durante o ano de 2017, 75\% das mortes foram de corpos negros. Entre 2007 e 2017, a taxa de mortalidade de negros cresceu $33,1 \%$, enquanto a mesma taxa entre não negros sofreu um aumento de $3,3 \% .^{10}$

O trabalho de difamação do corpo negro contido no riso é uma das instâncias socialmente importantes na materialização desses corpos. Portanto, acredito ser relevante discutir a maneira como uma prática situada como não séria e popular, ou seja, como "menos importante" na construção de realidades sociais, torna-se um cenário potente de exclusão que se faz através de uma estratégia narrativa da repetição, projetando limites, fixações e superfícies ao ser negro. Na próxima etapa, aprofundarei o humor racista, apresentando outras temáticas, tais como feiura e criminalização, que são "grudadas" à palavra "negro" como marca identitária. A proposta é abordar como esse enquadramento evoca traços de um contexto histórico da Primeira República que necessitou ressituar esse corpo recém-liberto, buscando os vestígios da escravidão e desumanização como mecanismos de poder e de diferenciação. Essa articulação implica pensar as permanências históricas desenhadas como marcas na superfície dos corpos negros e que são reiteradas através do riso. Além disso, dá margem para entendermos que é o modo como esse corpo foi desenhado historicamente que o torna um alvo risível.

Antes de passar para essa discussão, é importante explicitar como se deu a escolha das fontes. Durante sete meses, acompanhei diariamente e em vários horários diferentes os debates sobre humor racista na rede social Twitter. Direcionei meu olhar para as diversas publicações que envolviam a proposta do artigo no tempo da pesquisa, assim como utilizei o campo de busca da própria rede como estratégia para expandir a circulação dessas questões a momentos anteriores. Através de hashtags como \#mimimi, \#piadaracista e \#racismonãoépiada, por exemplo, tive acesso a um circuito mais amplo dessa disputa.

O processo envolveu produções de conteúdos por humoristas, pessoas reconhecidas publicamente no âmbito da política e do entretenimento e as práticas de usuários desenvolvidas entre respostas, curtidas e/ou compartilhamento dessas postagens, mas também comentários sobre o humor racista que não estavam diretamente ligados a uma personalidade midiática. Diante desse corpus, optei por analisar narrativas com maior circulação como critério de engajamento. Consequentemente, a escolha das fontes foi trançada pelas postagens com um grau maior de curtidas, compartilhamentos e comentários. Ressalto a presença de algumas análises em que uma determinada discussão foi expandida para além do Twitter e repercutiu em outras redes sociais, como Instagram ou YouTube, e, por essa razão, tornaram-se necessárias para a compreensão do debate gerado.

${ }^{10}$ Cf. Atlas da violência 2019. Brasília: Ipea, 2019, p. 49. 
É válido destacar ainda a incorporação de análises pontuais do riso racista na televisão e no cinema como suportes importantes no processo histórico de uma imagética cômica midiática através da qual é possível identificar a presença dessas temáticas como matrizes emocionais pela recorrência em piadas racistas, direcionadas ao corpo negro.

\section{O desenho do corpo negro risível como visibilidade e encarceramento}

Em 30 de junho de 2018, durante a Copa do Mundo, o humorista Julio Cocielo, conhecido nas redes sociais por suas performances cômicas, postou a seguinte frase em seu Twitter: "Mbappé conseguiria fazer uns arrastão top na praia hein". ${ }^{11}$ Após essa fala, inúmeros internautas da mesma rede social resgataram outras postagens de cunho racista do autor e as denunciaram através da hashtag \#racismonãoépiada. Além disso, os usuários citaram algumas marcas patrocinadoras do midiático, tais como Submarino, Coca-Cola, Adidas, Itaú e Unibanco, como forma de pressão. Esse processo gerou uma visibilidade negativa para o humorista. Além de contratos anulados com as marcas citadas, houve um cancelamento ${ }^{12}$ de seguidores de suas redes.

Entre as frases com tonalidades cômicas resgatadas, constam as seguintes: “Gritei VAI MACACA pela janela e a vizinha negra bateu no portão de casa para me dar bronca"; "Eu queria ter gravado um vídeo sobre o Dia da Consciência Negra, só que aí eu deixei quieto porque na cela não tem wi-fi"; “O Brasil seria mais lindo se não houvesse frescura com piadas racistas. Mas já que é proibido, a única solução é exterminar os negros"; e "Cara feia pra mim é fome. África, o país mais feio do mundo". ${ }^{13}$ Em função de uma perda considerável de seguidores - capital central dos modelos de negócios constituídos nas redes sociais -, o autor postou um pedido de desculpas:

Bom, vamo lá! Hoje eu fiz um tweet sobre o Mbappé e a piada se referia a velocidade dele devido a um lance do jogo, nada além disso! O tweet foi interpretado de mil formas diferentes e gerou uma grande discussão. Decidi deletar pois nunca fui de entrar em polêmicas, mas já era tarde demais, tinha tomado uma proporção enorme... pegaram alguns comentários antigos, de uns 8 anos atrás, que eu já havia feito aqui no Twitter, tenho até vergonha! Cara, como eu falava merda. Na época esses comentários infelizes tinham uma interpretação totalmente diferente de hoje, um momento delicado. Muitas vezes fui irônico, muitas vezes estava zoando. Não existe justificativa, isso fez eu me sentir muito mal só de imaginar ter sido uma pessoa escrota. Arrependido e APRENDIDO! Lição para vida! Nunca mais se repetirá! Peço desculpas publicamente por ter ofendido inúmeras pessoas, e como eu sempre digo: meu sonho sempre foi alegrar e motivar todos a acreditar nos próprios sonhos. Magoar alguém nunca foi a minha intenção, quem conhece minha história ou convive comigo, sabe como sou, e

\footnotetext{
${ }^{11}$ Ver Internautas "resgatam" tuítes racistas de youtuber Cocielo, que os deleta em seguida. O Estado de S. Paulo, 2018. Disponível em <https://emais.estadao.com.br/noticias/gente,internautas-resgatam-tuitesracistas-de-youtuber-cocielo-que-os-deleta-em-seguida-confira,70002380324>. Acesso em 10 dez. 2019.

${ }^{12} \mathrm{O}$ cancelamento é uma prática inscrita nas redes sociais para denunciar determinados posicionamentos políticos postados na internet, tais como o racismo. Os usuários entendem como capital o número de seguidores que determinado autor possui. Cancelar significa deixar de seguir e expor o autor da postagem denunciada simultaneamente.

${ }^{13}$ Ver O Estado de S. Paulo, op. cit.
} 
que jamais agiria dessa forma! Vivendo e aprendendo! Não vou entrar em nenhuma discussão, assumo meu erro! Desculpa! ${ }^{14}$

Em seu pedido de desculpas, ele relata que a comparação foi feita em relação à "velocidade devido a um lance do jogo, nada além disso!" O autor não discute a aproximação da cor do jogador com práticas criminosas, vinculadas aos arrastões. Ao contrário, direcionou suas desculpas para as interpretações de "mil formas diferentes" dos leitores, apagando com isso a ideia de intenção ofensiva contida em sua postagem. Ele segue o texto pedindo desculpas, mas pelos resgates de postagens racistas antigas ("oito anos atrás"), utilizando o tempo como justificativa para os "comentários infelizes". Embora o autor reconheça o cunho racista de suas piadas anteriores, enfatiza a perspectiva de falta de intenção, utilizando como estratégia o apelo emocional para tocar o coração dos usuários: "meu sonho sempre foi alegrar e motivar todos a acreditarem no seu próprio sonho". Com esse modelo de escrita, Cocielo reitera um imaginário sobre humor grudado à ideia de brincadeira sem tensionar a violência expressa em suas piadas direcionadas à construção de um alvo risível.

O humorista gravou um vídeo de seis minutos para o seu canal no YouTube (Canal Canalha) e o disponibilizou em sua página do Instagram, reforçando o pedido de desculpas e o argumento de que sua performance direcionada ao corpo negro era fruto de "ignorância" (título do vídeo). Nesse vídeo, mais uma vez, ratifica o posicionamento de que seu comentário sobre Mbappé estava relacionado à velocidade do jogador. Alega, porém, que reconhece e compreende "a revolta das pessoas" e, ainda, que foi buscar aprender, conversando "com pessoas" para entender sobre "racismo institucional e racismo velado". Cocielo a dizer que "é uma parada que a gente só precisa prestar a atenção nas estatísticas, por exemplo, muito negro morre sendo confundido como bandido. Também teve o caso de um negro que ele tava entrando no carro dele e ele foi preso acusado de tá roubando o próprio carro. No meu caso, a minha ignorância foi combatida com conhecimento".$^{15}$

A correlação entre piada racista e as camadas da violência, incluindo a física, é fundamental para o entendimento de como o humor corrobora para a construção de um sistema de exclusão quando seus alvos risíveis são sujeitos que historicamente sempre foram colocados às margens de um ideal de corpo dominante. Esse reconhecimento de Cocielo não invalida suas ações, mas o recoloca como um humorista de internet que não se nega a dialogar com as demandas identitárias de seguidores insatisfeitos, abrindo para a possibilidade de novos seguidores e de seu "descancelamento" em rede.

Entretanto, vários usuários do Twitter recuperaram uma imagem em que Cocielo "curtiu" o comentário de @arlingtonxops7 direcionado a esse episódio, atitude que esvazia sua autocrítica em relação ao humor racista. A usuária Jeniffer Prioli repostou a imagem acrescentando a fala: “Ontem o Cocielo lançou 1 vídeo pedindo desculpas e hj (sim, depois do tão sincero vídeo) já

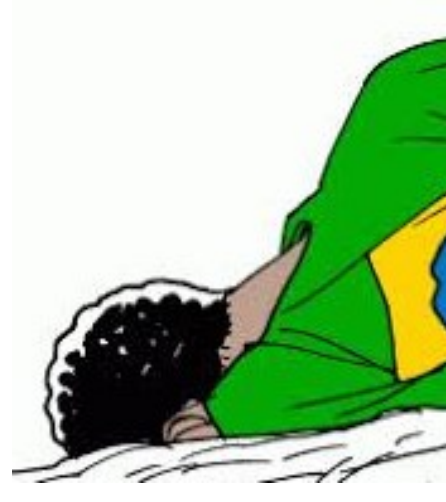

14 COCIELO, Julio. Sobre que tudo que tá rolando. @cocielo, 30 jun. 2018. Disponível em $<$ https://twitter.com/cocielo/status/1013184108896440321>. Acesso em 10 dez. 2019.

15 Idem, Ignorância. Canal Canalha, 4 jul. 2018. Disponível em $<$ https://www.youtube.com/watch?v=gMCVAecsIoI\&t=161s >. Disponível em 10 dez. 2019. 
curtiu um comentário falando q é tudo mimimi. Morro q não deixou nem o cadáver esfriar e como tem gte [gente] a [que] compra texto escrito por assessoria". ${ }^{16}$

A postagem curtida por Cocielo defende a permissividade das práticas cômicas como algo constitutivo do riso e do "senso de humor", apagando uma orientação histórica que direciona o riso a determinados alvos. Diz o texto: "Hoje em dia TUDO é preconceito ou machismo. Senso de humor hoje em dia é praticamente 0.0 é o número de pessoas que nunca praticaram tal ato que eu citei. Sociedade hipócrita, reis do mimimi. Deixem de inventar coisa nas suas cabeças, o que se passa na sua não é necessariamente o que se passa na dos outros. E antes de julgar os outros, saiba que julgar as pessoas também é feio, assim como vocês acham que tal coisa é inaceitável". ${ }^{17}$

Além de defender a suposta liberdade do riso sem questionar o investimento em determinados alvos risíveis, o seguidor criticou o julgamento das redes sociais contra o humorista, mas não questionou o conteúdo das postagens de Cocielo como um lugar de julgamento e de desqualificação do outro. Esse comentário revalida a ideia de que através do riso tudo é permitido e de que "ter senso de humor" significa neutralidade e falta de projeto ideológico. Então, o riso entendido como não sério é ostentado como um espaço que separa diversão e política, potencializando contraditoriamente, mas não de maneira aleatória, sua dimensão política.

Segundo Mikhail Bakhtin, o riso na modernidade foi marcado pela separação entre sujeito e objeto do riso, emergindo um tipo de comicidade que é orientada para formulação de hierarquias sociais e direcionada a alvos risíveis específicos e contextualizados historicamente:

Essa é uma das diferenças essenciais que separam o riso festivo popular do riso puramente satírico da época moderna. O autor satírico que apenas emprega o riso negativo, coloca-se fora do objeto aludido e opõe-se a ele; isso destrói a integridade do aspecto cômico do mundo, e então o risível (negativo) torna-se um fenômeno particular. Ao contrário, o riso popular ambivalente expressa uma opinião sobre um mundo em plena evolução no qual estão incluídos os que riem. ${ }^{18}$

Durante a pesquisa de dados, coloquei no espaço de busca do próprio Twitter a hashtag \#Piadaracista para visualizar que tipo de postagem é complementada com essa significação. A maior parte das postagens é de usuários brancos utilizando o termo como identificação e defesa desse tipo de humor. Não houve nenhum usuário branco utilizando a hashtag como forma de denúncia, e a maioria das piadas criminalizava o corpo negro, como nestes exemplos:

\footnotetext{
${ }^{16}$ PRIOLI, Jennifer. Ontem o Cocielo lançou 1 vídeo pedindo desculpas. @jennyprioli, 5 jul. 2018. Disponível em <https://twitter.com/jennyprioli/status/1014904395421704192>. Acesso em 10 dez. 2019.

${ }^{17} \mathrm{Idem}$.

${ }^{18}$ BAKHTIN, Mikhail. A cultura popular na Idade Média e no Renascimento: o contexto de François Rabelais. São Paulo: Hucitec, 1996, p. 74.
} 
1) Por que caixão de negro só tem duas alças? Porque lixeira não tem 4. \#piadaracista. ${ }^{19}$

2) Eu não sou racista por que racismo é crime... crime dá cadeia e cadeia é coisa de prêto!!" \#piadaracista. ${ }^{20}$

3) Qual a única coisa que brilha em um preto? As algemas. \#piadaracista. ${ }^{21}$

4) Inclusive ceis vão nessa festa de preto vão sair tudo sem carteira. \#Piadaracista, \#Fodac, \#Falomesmo. 22

5) Vou me pintar de preto. Aí tinha certeza que não teria futuro. \#Piadaracista, \#Quevenhaohate. ${ }^{23}$

O circuito pelo qual as narrativas cômicas são articuladas, entre mídia e cotidiano, humoristas/programas cômicos e usuários das redes sociais, constitui-se de frações por meio das quais cristaliza-se uma prática de visibilidade do corpo negro: ao insistir na remodelação desse corpo como animalesco, criminoso, feio e morto de fome (exemplificados nas postagens de Cocielo e dos usuários citados), apaga-se o que esse corpo negro poderia ser. Há um investimento que se processa pelo simbólico em limitar e fixar sentidos. Portanto, através da orientação excessivamente codificada nas narrativas cômicas racistas, o corpo negro passa a ser visível como aquele que deve ser subjugado, temido e odiado.

A questão racial se tornou central no debate sobre cultura e sociedade no Brasil, e esse debate foi projetado na cultura massiva do século XX. Essa contextualização é importante porque coloca em evidência como as marcas na superfície do corpo negro visualizadas no humor racista foram constituídas e tornaram-se temáticas relevantes de um imaginário cômico popular no Brasil. Tomo como marcos do debate o período marcado pela construção da Primeira República e o fim da escravatura, momento em que o corpo negro se apresentou como questão no pensamento intelectual brasileiro. Célia Maria Marinho de Azevedo sugere que, mesmo antes do processo do fim da escravidão, marcas na superfície do corpo negro, tais como cor, cabelo e características físicas, já existiam como aspectos de diferenciação: “os negros livres já de há muitas gerações, mesmo miscigenados, frequentemente traziam impressas as suas origens africanas, as marcas dos seus antepassados escravos, e assim ficavam entregues à possibilidade de serem tratados com desprezo e violência". ${ }^{24}$

Essa noção de inferioridade do corpo negro propagou-se e consolidou um imaginário vinculado à elite intelectual brasileira durante o século XIX, principalmente quando a perspectiva de uma sociedade forjada no trabalho livre, liberal e republicana emergiu como projeto nacional. De acordo com

\footnotetext{
19 JR, Madruguinha. Por que caixão de negro só tem duas alças? Porque lixeira não tem 4. @madruguinha_jr., 26 nov. 2019. Disponível em <https://twitter.com/madruguinha_jr/status/6086468288>. Acesso em 10 dez. 2019.

${ }^{20}$ CASTELO, Eduardo. Eu não sou racista porque racismo é crime. @casteloeduardo, 2 set. 2019. Disponível em <https://twitter.com/casteloeduardo/status/22818170628>. Acesso em 10 dez. 2019.

21 SPORT. Qual a única coisa que brilha em um preto?. @cristofobia, 6 de out. de 2012. Disponível em <https://twitter.com/cristofobia/status/26586080856>. Acesso em 10 dez. 2019.

22 MILA. Inclusive ceis vão nessa festa de preto vão sair tudo sem carteira. @milalopes, 6 out. 2012. Disponível em <https://twitter.com/milalopes_/status/254728510277554176>. Acesso em 10 dez. 2019.

23 CELSOEFM. Vou-me pintar de preto, aí teria a certeza que não tinha futuro. @delet-d, 20 out. 2015. Disponível em <https://twitter.com/delete_d/status/656603526798397440>. Acesso em 10 dez. 2019.

24 AZEVEDO, Célia Maria Marinho de. Onda negra, medo branco: o negro no imaginário das elites - século XIX. São Paulo: Annablume, 1987, p. 34.
} 
Lilia Schwarcz, além dos problemas circunscritos à mão de obra, surgidos a partir da luta abolicionista, "à conservação de uma hierarquia social bastante rígida, parecia ser preciso estabelecer critérios diferenciados de cidadania". Nesse sentido, segue a autora, a raça "se transforma em um novo argumento de sucesso para o estabelecimento das diferenças sociais". ${ }^{25}$

Ainda segundo essa autora, a chegada das teorias raciais do século XIX, originadas na Europa - principalmente o naturalismo e o darwinismo, que adotaram a biologia como marcadores sociais -, assegurou cientificamente o processo de construção social baseado na subalternização do corpo negro. Em paralelo, Azevedo aponta o projeto simbólico de identificação do corpo negro como perigoso. Para ela, os levantes negros - entre eles, o levante dos malês, em 1835 - projetaram o medo da população branca como um pressuposto para a imaginação do perigo como marca na superfície do corpo negro. Desse modo, "a raça inferior negra, embora escravizada, teria determinado a má evolução ou a não evolução dos brasileiros brancos. E assim despido da imagem de vítima, que estava então sendo construída pelos abolicionistas, o negro passava a incorporar a de opressor de toda uma sociedade". ${ }^{26}$

As temáticas como incivilidade, feiura e a vinculação do perigo se instauram como projeto de identificação que alinhava traços fenotípicos a características difamatórias encarcerando o corpo negro a significados históricos que se reatualizam em práticas midiáticas e cotidianas. Na ótica de Pedro Vinicius Asterito Lapera ${ }^{27}$, o cinema foi um meio central de divulgação do imaginário racial, durante o período de formação de uma cultura massiva. Analisando os anúncios publicitários do cinema no Jornal do Brasil, durante os anos de 1908 e 1909, ele relata como a raça se insere nas narrativas fílmicas e se entrelaça com os gêneros massivos, entre eles o cômico. Para o autor, esse processo funcionou como um importante operador na formação de gosto no senso comum. Reproduzo abaixo um dos reclames citados:

Um casal de Creoulos em Paris - A maior novidade do dia. Bella e extensa; fita completamente nova para esta capital, sem competidora nas bellissimas paysagens que se apresentam a vista do espectador. Um bello e pandego casal de creoulos, desembarcando em Paris é logo assaltado por alguns refinados ladrões, com a desculpa de servir-lhes de ciccerone tratam a caça [...] momento de extorquir-lhe dinheiro, porém, o casal mais esperto que eles propõe pregar-lhes um bom logro, enchendo um papel fingindo cheque do Banco Paris-Brésilien vão entregando aos mesmos, estes depois de juntarem uma porção encaminham-se para o Banco descontal-os, mas oh! Decepção fatal, em vez de receberem o dinheiro, são presos e levados à prisão, enquanto que o casal se ri a valer da peça pregada aos larápios. ${ }^{28}$

Através do estereótipo que assume como características do corpo negro a "malandragem ('o casal mais esperto que eles') e a falta de contenção caras a uma cultura de elite ('enquanto o casal que se ri a valer da peça prega-

${ }^{25}$ SCHWARCZ, Lilia Moritz. O espetáculo das raças: cientistas, instituições e questão racial no Brasil. São Paulo: Companhia das Letras, 2019, p. 24.

${ }^{26}$ AZEVEDO, Célia Maria Marinho de, op. cit., p. 69.

${ }^{27}$ LAPERA, Pedro Vinicius Asterito. Ideário racial na "Belle Époque Tropical": o caso do cinematographo. Revista do Arquivo Geral da Cidade do Rio de Janeiro, n. 6, Rio de Janeiro, 2012. Disponível em $<$ http://wpro.rio.rj.gov.br/revistaagcrj/wp-content/uploads/2016/11/e06_a16.pdf >. Acesso em 10 out. 2019.

${ }^{28}$ Idem, ibidem, p. 149. 
da aos larápios')", o risível se forma como convite ao público para assistir ao filme e como incorporação de critérios de identificação, diferenciação e exclusão do corpo negro simultaneamente. O cinema oferece um método de validação de hierarquias raciais através de práticas recreativas que se desprendem de "categorias que se pretendem objetivas". ${ }^{29}$

Parto do pressuposto de que a consolidação da televisão no Brasil colabora para a amplificação dos processos de identificações sociais, em virtude da formação de grandes audiências massivas em diferentes cidades brasileiras. Na década de 1960, o projeto de construção de um parque industrial no Brasil, capitaneado pelos empresários e pelo estado ditatorial, promoveu o crescimento de um projeto de televisão nacional vertical, fortalecendo as grandes emissoras abertas e situadas no sudeste do país, tais como Rede Globo, SBT, TV Record e Bandeirantes (atualmente renomeada como Band). O pouco investimento na formação de televisões locais, somado a demandas de produção em larga escala, favoreceu a diminuição de sentidos múltiplos, implicando a projeção de narrativas hegemônicas e compostas por ideais que conformavam o corpo branco como ideal civilizatório.

O humor foi um importante componente na formação de uma cultura televisiva, espraiado em programas segmentados como humorísticos, mas também em enredos que usufruíram do diálogo entre diferentes gêneros massivo-populares em sua configuração, tais como revistas eletrônicas, programas de auditório e telenovelas. Moreira faz uma análise de personagens humorísticos negros - entre eles, Mussum e Tião Macalé, visualizados em “Os Trapalhões" e Adelaide, em "Zorra Total", todos de programas transmitidos pela TV Globo, rede de maior audiência no Brasil desde a década de 1970.

No caso de Tião Macalé, a feiura tornou-se o elemento constitutivo do riso. Caracterizada pela falta de dentes na boca e por caretas que, segundo o autor, criavam uma analogia entre a imagem de Macalé e a de um macaco, a ideia de feiura foi associada à animalização do corpo do personagem, interpretado como não humano. Essa imagem caricatural tinha como propósito projetar um sentimento de asco pelo personagem através da configuração de sua aparência: "ele era retratado de forma infantilizada, como pessoa pouco inteligente, ou como figura típica do malandro ou ladrão, o indivíduo que sempre procura ter uma vida fácil trapaceando ou enganando as pessoas". ${ }^{30}$

O personagem Mussum foi marcado pelo estereótipo da malandragem, carregado pela imagem da bebedeira como referência central em comparação aos brancos, que se apresentavam como sóbrios. Piadas em referência a sua cor, cabelo e porte físico foram constantes, e as respostas em tons raivosos proferidas por Mussum contra esses xingamentos também se tornavam reguladoras da comicidade, tais como "macaco é teu passadis!", "se disser urubu vai ter outro pau aqui fora!". Em esquete que encenava o encontro entre Mussum, Zacarias e Dedé em um restaurante italiano, Mussum foi xingado três vezes por expressões que vinculavam seu corpo a animais: "boi da cara preta!", "galinha de macumba" e "morcegão". O intuito era provocar ira no personagem negro. Para tanto, há uma desqualificação do corpo negro por inter-

\footnotetext{
${ }^{29}$ Idem, ibidem, p. 151.

${ }^{30}$ MOREIRA, Adilson, op. cit., p. 104.
} 
médio de analogias entre práticas culturais africanas, como a religião, que é "colada" à figura de um animal.

Em Adelaide, a feiura da personagem reatualiza características constitutivas de Tião Macalé, tais como a falta de dentes na boca. Ademais, os traços fenotípicos característicos de uma matriz africana são exacerbados: o cabelo comprido e crespo, o nariz grande. Adelaide é uma mulher pobre que evoca o estereótipo da malandragem como estratégia para vincular a criminalização ao seu corpo.

Pensar através desses permite perceber como os meios massivos foram vetores de uma moralidade forjada na desigualdade racial. O recalque do corpo negro "colado" a características como feiura, malandragem, irracionalidade e criminalização é uma constante que evidencia o corpo branco como um "tipo ideal" ${ }^{31} \mathrm{O}$ humor racista conclama o público a rir sem a necessidade de culpas ou constrangimentos por conta da suposta falta de intenção atribuída à comédia. Portanto, o riso racista remarca o corpo negro de maneira amenizada e por isso torna-se tão eficaz como projeto político.

Na próxima etapa, realizarei uma discussão sobre o desenho do corpo negro na tensão que se estabelece como disputa entre riso e brincadeira. A intenção é pensar paralelamente os desenhos do corpo negro e o fechamento de sentidos que é dado ao riso. Através desse diálogo, proponho apontar como a piada racista torna-se um mecanismo importante na confabulação de um projeto colonizador. Ademais, direcionarei a análise para o circuito político contido nas emoções, a partir das imagens de dor e ódio, para pensar a política contida no riso racista como particularidades de uma ética cômica situada no popular.

\section{As disputas de sentido constitutivas do riso como brincadeira e os senti- mentos mobilizados}

No Código Penal brasileiro, são considerados crimes de injúria racial ações difamatórias que configuram dolo - reconhecimento de que uma ação é ilegal e mesmo assim possuir a intenção (animus) de executar. Em contraponto ao animus injuriandi, há outros tipos de intenção que são consideradas sem dolo: animus criticandi (tntenção de criticar), animus narrandi (intenção de narrar um acontecimento) e animus jocandi (intenção de brincar, fazer rir). ${ }^{32}$

É interessante perceber como o humor é concebido no campo jurídico. Se, por um lado, o entendimento de falta de dolo favorece a intensificação de narrativas de humor homofóbicas, misóginas, xenofóbicas e racistas - considerando que são acobertadas legalmente - por outro, essa mesma condição pode ser utilizada como uma proteção para práticas cômicas dissidentes que utilizam a difamação para desconstruir os diferentes preconceitos citados. Em princípio, a vinculação entre riso e brincadeira legalmente pode ser entendida

\footnotetext{
${ }^{31}$ Cf. WEBER, Max. A objetividade do conhecimento nas ciências sociais. In: COHN, Gabriel (org.). Weber: Sociologia. São Paulo: Ática, 1999.

32 Ver SANTOS, Karla Cristina. Relevância jurídica dos conceitos de significado, referência, contexto e intenção nos casos de injúria qualificada. Revista do Seta, n. 4, Campinas, 2010. Disponível em <http://revistas.iel.unicamp.br/index.php/seta/article/view/943/694>. Acesso em 10 dez. 2019.
} 
em sua dimensão escorregadia, derrapando os sentidos com os quais se disputam os desenhos nos corpos risíveis.

Entretanto, essa categoria jurídica legal está ancorada naquilo que chamo de disciplinamento do corpo cômico na modernidade ${ }^{33}$ e que redimensiona o sentido do riso e do popular como lugar de explicação de mundo. Em seu relato sobre o humor na Idade Média, Bakhtin ${ }^{34}$ relacionou o riso com as matrizes populares, nas reuniões carnavalescas concebidas em praças públicas. A figura do cômico-popular se originou no campo da não seriedade, vinculado às ações emocionais, cênicas e excessivas, ou seja, como traço estético que não invalida posições políticas investidas através de um sistema cômico de imagens popular. O brincante era entendido como ideológico, impetrando uma cosmovisão que disputava com a razão um sentido sobre o mundo.

Zombaria, grotesco, blasfêmia, difamação, escárnio, inocência, maldizer, amargura, ridicularização, entre outros, configuram-se como um sistema cognitivo de repertórios cômicos. A ideia de brincadeira como sinônimo de riso não presume necessariamente o descolamento da violência e do ataque a alvos específicos, pois as emoções são operadores narrativos inscritos nas artes de narrar a vida comicamente. Sigo o traçado de Aaron Smuts ${ }^{35}$ na premissa de que as narrativas cômicas devem ser pensadas como ações que apresentam significados éticos, pois possuem a capacidade de gerar dolos (danos) ao corpo desenhado comicamente.

No pensamento filosófico ocidental do século $X X$, o riso foi localizado como uma experiência do não lugar - uma espécie de operação narrativa consagrada na dúvida, favorecendo uma crítica à racionalidade e suas normatizações. ${ }^{36}$ Esse caráter redentor beneficiou o entendimento da prática cômica como libertária e amoral e adentrou na esfera cultural, midiática e cotidiana, assentado nas disputas entre o politicamente correto e o incorreto. O colunista da Folha de S. Paulo Joel Pinheiro criticou negativamente o politicamente correto em vários de seus textos. Entre eles há um que demarca seu ponto de vista no campo próprio da comicidade: "nosso humor, que sempre foi amoral, é agora taxado de imoral. Resta saber se a alternativa do humor politizado é possível. Rir por obrigação não tem graça; pode provocar estresse" ${ }^{37}$

\footnotetext{
33 Além da dimensão que desliza o sentido da palavra "brincadeira" apegada à comicidade, investigada neste artigo, o disciplinamento do corpo cômico na modernidade se deu por diferentes camadas, entre elas 1) a contenção dos gestos corporais inscritos no corpo que gargalha como modo comportamental, discutido por Jacques Le Goff; 2) a perspectiva de um pensamento sobre riso atravessado por um distanciamento crítico que afasta as emoções do entendimento sobre o riso, na teoria de Henri Bergson; 3) a polarização entre riso ofensivo e inofensivo, em Sigmund Freud; e 3) aquilo que designei, em outro trabalho, como assepsia do grotesco como marca narrativa cômica. Ver LE GOFF, Jacques. O riso na Idade Média. In: BREMMER, Jan e ROODENBURG, Herman (orgs.). Uma história cultural do humor. Rio de Janeiro: Record, 2000, BERGSON, Henry. O riso: ensaio sobre a significação da comicidade. São Paulo: Martins Fontes, 2004, FREUD, Sigmund. Os chistes e sua relação com o inconsciente. São Paulo: Companhia das Letras, 2017, e CAMINHA, Marina. O corpo juvenil televisivo: diálogos entre televisão, juventudes e consumo nas ondas de Armação Ilimitada e TV Pirata. Tese (Doutorado em Comunicação Social) - UFF, Niterói, 2012.

34 Ver BAKTHIN, Mikhail, op. cit.

35 Ver SMUTS, Aaron. The ethics of humor: Can your sense of humor be wrong? Ethical Theory and Moral Practice, v. 3, n. 13, Houten, 2010. Disponível em <10.1007/s10677-009-9203-5>. Acesso em 10 out. 2019.

36 Ver ALBERTI, Verena. O riso e o risível na história do pensamento. Rio de Janeiro: Jorge Zahar, 2002.

37 PINHEIRO, Joel. O politicamente correto quer regular as piadas. Folha de S. Paulo, 2015. Disponível em <https://m.folha.uol.com.br/ilustrissima/2015/01/1575799-o-politicamente-correto-quer-regular-aspiadas.shtml> . Acesso em 20 out. 2019.
} 
O colunista reatualiza um diálogo entre politicamente correto e senso de humor como se a ideia de moralidade retirasse do riso sua dimensão engraçada. Chega mesmo a criticar a postura de Laerte em apontar os reforços de estereótipos derrogatórios contidos no humor de "Os Trapalhões". Entretanto, Renato Aragão ao discutir sobre seus trabalhos cômicos foi em um caminho diferente do colunista. Para o humorista, o politicamente correto é um "policiamento que é justo. Eu acho justo. Você pode fazer o humor sem prejudicar ninguém". Nesse sentido, ele segue dizendo que se pudesse modificar algumas cenas cômicas do programa "focaria mais no respeito; hoje todos ganharam seu espaço: negro, gordo, baixinho como eu, nordestino". 38

Articular a definição de "ser engraçado" com a amoralidade é um pacto estratégico como projeto pedagógico. Paralelamente, a amoralidade contida na palavra "brincadeira", quando apegada ao riso, contribuiu para uma desqualificação do riso popular. O silenciamento das emoções no corpo cômico e, consequentemente, sua descorporificação orientaram vários estudos qualificatórios em que o critério de diferenciação se configurou pela racionalização do riso, tais como a teoria de Henri Bergson. ${ }^{39}$ Essa distinção que circulou na crítica cultural e na academia permanece funcionando como formação de gosto no senso comum, promovendo uma hierarquização e inferiorização de audiovisuais cômicos nos quais as matrizes populares são mais acentuadas narrativamente. ${ }^{40}$

Sigo os rastros de Georges Minois quanto ao modo de entender o riso: "alternadamente agressivo, sarcástico, escarnecedor, amigável, sardônico, angélico, tomando as formas da ironia, do humor, do burlesco, do grotesco, ele é multiforme, ambivalente, ambíguo. Pode expressar tanto a alegria pura quanto o triunfo maldoso, o orgulho ou a simpatia". ${ }^{41}$ Dessa forma, pensar o riso como brincadeira, desvinculando-o de operações remarcadas por práticas ofensivas, constitui-se como um fetiche da comicidade popular, pois apaga o trabalho que é feito historicamente para deslizar e transformar o sentido da brincadeira.

Acredito que uma das maneiras de compreensão desse processo perpassa pelas disputas simbólicas atribuídas ao riso - as relações entre violência, ofensas, brincadeira e neutralidade, bem como as maneiras como o riso conclama o público a formar uma impressão do outro através das emoções como operadores narrativos. Assim, o que chamo de desenhos de corpos risíveis é um direcionamento dado a impressionar. A exacerbação de traços fenotípicos, trejeitos e marcas históricas cria uma caricatura do corpo. Esta, por sua vez, é acionada para fazer "grudar" adjetivações, aderindo à pele de tal forma que naturaliza e fixa a impressão, presumindo que a identidade é um dado a priori.

"Esse corpo que é" torna-se um corpo fetichizado, silenciando como esse desenho foi trabalhado historicamente. "Esse corpo que é" adquire um valor na forma como é sentido pelo espectador do riso: como menor e subor-

\footnotetext{
38 ARAGÃO, Renato apud ISSA, Tatiana e BARRA, Guto. Viver do riso, Rio de Janeiro, Producing Partners/ Canal Viva/Rede Globo, 2018 (entrevista exibida pelo canal Viva e Globoplay).

${ }^{39}$ Ver BERGSON, Henri, op. cit.

${ }^{40}$ Ver BOURDIEU, Pierre. Questões de Sociologia. Rio de Janeiro: Marco Zero, 1983.

${ }^{41}$ MINOIS, Georges. A história do riso e do escárnio. São Paulo: Editora Unesp, 2003, p. 10.
} 
dinado; como perigoso e violentado; como feio e odiado; entre outras possibilidades. Nessa perspectiva, o disciplinamento do corpo cômico na modernidade deixa transparecer uma ambivalência através da qual percebo a política em disputa fabulada em desenhos corporais risíveis. Simultaneamente, há uma fixação de sentidos interligados entre diversão e amoralidade como denominação do gênero cômico, enquanto uma multiplicidade de emoções (que não apenas o fazer rir) são evidenciadas como modos de narrar constituintes do humor. Por tal via, as marcas emocionais projetam visões de mundo que permanecem nas narrativas cômicas como sinônimos do "direito dos sujeitos a rirem" e/ou "é só uma piada".

Portanto, o fetiche se dá em duas direções: no da produção histórica que universalizou e naturalizou determinadas características orientadas para desqualificar o corpo negro, mas, também, no deslizamento simbólico que é dado ao riso/brincadeira na modernidade. Desapegar essas duas palavras brincadeira e riso - significa colocar o riso em um espaço da seriedade, mantendo a estética do popular em lugar desqualificado, menor e sem valor ideológico. Violenta os corpos populares e sobrepõe a razão às emoções, apagando com isso os jogos políticos que envolvem a emoção em nossas práticas culturais.

Esse duplo fetiche, torna-se uma chave relevante para entendermos como o riso pode ser colonizador. Entretanto, a celebração da ofensa e da violência contidas no riso também corre o risco de se tornar uma mercadoria. A questão da conveniência que apontei é a de corpos privilegiados se sentirem no direito de "reclamar" a ofensa, criando uma equivalência de sentidos ao estatuto da violência que descontextualiza o lugar desses corpos na história. A reivindicação de algumas pessoas brancas de sofrerem racismo reverso pode ser tomada como um exemplo. Aprofundarei essa discussão através do entendimento das emoções como política.

O riso conclama o corpo do outro a experimentar uma emoção através da qual uma moral passa a ser experimentada. O riso racista, por exemplo, pode tornar presente a dor como lugar de experimentação do riso através da memória desses corpos violentados historicamente quando são significados como criminoso, feio e animalesco. Podem ser desenhados para serem odiados através dos usos desses mesmos signos, como sugerem José Dagoberto Fonse$\mathrm{ca}^{42}$ e Moreira. ${ }^{43}$

Sara Ahmed propõe pensar como a emoção age para tornar o objeto "saturado de afeto", implicando a criação "de superfícies e limites que permitem ao indivíduo e ao social serem delineados como se fossem objetos". ${ }^{44}$ Para tanto, oferece um modelo analítico que entende a emoção no processo de sua circulação entre signos. A emoção deixa de ser localizada como algo pertencente ao sujeito, tanto do ponto de vista psicológico (interno), quanto sociológico (algo que vem de fora para o sujeito).

\footnotetext{
${ }^{42}$ Ver FONSECA, José Dagoberto, op. cit.

${ }^{43}$ Ver MOREIRA, Adilson, op. cit.

${ }^{44}$ Traduções de "saturated with affect" e "the very surfaces and boundaries that allow the individual and the social to be delineated as if they are objects". AHMED, Sara. The cultural politic of emotion. United Kingdom: Edinburgh University Press, 2014, p. 10 e 11.
} 
Para ela, as emoções não estão presentes nem no sujeito nem no objeto; adquirem valor através de sua circulação. Esse processo está vinculado a uma historicidade que fixa as emoções nos sujeitos e objetos narrados - "history sticks" 45 , à medida que circula. Essa historicidade pegajosa ${ }^{46}$ é o que orienta a narrativa, contribuindo para uma economia afetiva - seu conceito principal. Nessa lógica, os processos de circulação narrativos aumentam os graus de saturação das emoções apegados aos corpos narrados como um efeito de uma economia afetiva, como equivalente a "acumulação de valor afetivo". O aumento de valor atua em consequência dos movimentos entre os signos. "Quantos mais os signos circulam, mais afetivos eles se tornam". O descolamento das emoções como algo do sujeito envolve pensar que "o movimento lateral e para trás das emoções" não é parte constituinte dos "desenhos de um sujeito", pois o projeto econômico emocional é social, material e psíquico. É o movimento das emoções "entre figuras que trabalha para materializar a própria superfície dos corpos coletivos". ${ }^{47}$

A compreensão da emoção como inserida em um processo econômico ajuda a entender os deslizamentos e as fixações de sentido que atuam no desenho do corpo negro pelo humor, pois aponta para o investimento que é realizado em tornar determinada emoção apegada a esse corpo. Busco pensar o papel social das emoções no trabalho de vinculação do riso à ausência de intenção ofensiva e ao desenho fetichizado do corpo negro simultaneamente. Retomando Ahmed, as emoções só se tornam políticas na narrativa. Então, as emoções podem ser pensadas como lógicas operacionais da comicidade ou, na acepção de Cleise Furtado Mendes, como gêneros afetivos: “certas famílias de obras aparentadas por um mesmo modo de dispor ou mover os afetos do leitor ou espectador". ${ }^{48}$ Desse modo, é possível pensar as ofensas contidas nas piadas racistas como uma ferida que envolve um deslizamento entre dor e ódio como contorno do corpo negro.

Essas emoções são forjadas através da relação histórica entre as palavras e o corpo negro e, quanto mais elas circulam, mais valor afetivo acumulado adquirem. Seguindo a premissa de Ahmed, a memória evocada pela significação do corpo negro como feio, animalesco ou criminoso torna esse corpo um objeto das emoções em duas direções: na emoção que é experimentada no encontro com essa memória, mas também no direcionamento que é dado ao que é lembrado. Nesse sentido, a piada racista cria uma impressão sobre o corpo negro e causa uma impressão simultaneamente no processo de encontro dessa piada com os corpos dos espectadores. Retomando a perspectiva da

\footnotetext{
${ }^{45}$ AHMED, Sara, op. cit., p. 47.

${ }^{46}$ O termo "pegajosidade" foi utilizado na tradução da palavra stickness na versão em espanhol do livro. Optei por esse uso por entender essa nomeação como mais satisfatória em contraposição a "aderência". A imagem da pegajosidade implica um duplo sentido na ideia de grude como algo que se cola, mas também algo elástico/viscoso, como uma espécie de massa de modelar que pode ser construída e desconstruída. Desse modo, ajuda a entender com mais precisão os efeitos da história no corpo cômico em suas dinâmicas que deslizam entre a hegemonia e a dissidência. Ver idem, La política cultural de las emociones. México: Unam, 2015.

47 Tradução de "the accumulation of affective value"; "the more signs circulate, the more affective they become"; "it suggests that the sideways and backwards movement of emoticons" e "between figures that Works to materialise the very 'surface' of collective bodies". Idem, The cultural politic of emotion, op. cit., p. 47. ${ }^{48}$ MENDES, Cleise Furtado. A gargalhada de Ulisses: a catarse na comédia. São Paulo: Perspectiva, 2008, p. 212.
} 
ofensa como ferida, a dor como marca na superfície descortina as práticas violentas imputadas a esse corpo negro. É possível pensar o questionamento da ausência de ofensa atribuída ao riso como uma política de desigualdade racial.

Para Ahmed, a dor é contingente e exige reconhecimento porque está em circulação, envolve afetar e ser afetado. Pode ser experimentada como "solitária", mas nunca como "particular". É a isso que a autora chama de socialidade da dor. Se as emoções desenham o corpo, definindo as fronteiras do eu e do outro, a dor desenha a identidade do corpo negro. A autora alerta ainda para o risco de fetichização da dor quando ela passa a significar uma identidade a priori, pois a mercantilização da dor implica uma equivalência das formas de sofrimento, permitindo que o "prejuízo se torne um direito que é disponível simultaneamente para todos os outros". ${ }^{49}$

Por esse ângulo, é também através da reivindicação da dor que a celebração da ofensa e da violência como atributos do riso pode ser comoditizada, levando corpos privilegiados a exigirem direitos iguais. A comercialização da dor se transforma em ausência de dor nos corpos subalternizados. Ao discutir as camadas genocidas imputadas ao corpo negro, Ana Luiza Pinheiro Flauzina chama a atenção para a imagem naturalizada da dor: "se o racismo experimentado no processo escravista inscreve a violação de corpos como prática sistêmica, a desumanização é seu legado mais caro. Esse padrão arraigado no imaginário é ferramenta poderosa que naturaliza o vilipêndio, a tortura e a morte como destino natural do contingente negro". ${ }^{50}$ Portanto, as relações entre riso ofensivo e riso inocente emergem como marcas simbólicas derrapantes e escorregadias. A violência do humor é um capital em disputa. É através desse processo que o riso pode ser apreendido como uma instância central de validação de um imaginário hegemônico.

Acredito que o apagamento da ofensiva cômica é violação da história desses corpos desenhados, assim como da própria história da comicidade. Parto do pressuposto de que um modo de descortinar as pedagogias colonizadoras contidas no humor seja insistir em situar os alvos risíveis no contexto histórico e, como sugere Ahmed, sem aprisioná-los ao passado para que a dor não possa ser identificada como uma dor que é de todos. As formas de afetação da dor nos corpos são desiguais e se relacionam com a maneira como esses corpos estão situados no presente. Não é uma emoção encarcerada no passado; o passado histórico remodela esse corpo ferido e apaga o que ele poderia ser. Contudo, a violência que se reatualiza no riso racista permanece como contingência de lesões nos corpos negros no presente.

Para finalizar, faz-se necessário discorrer sobre a maneira como a política do ódio opera. A criminalização do corpo negro é perpassada pelo modo como esses corpos são desenhados para serem odiados. Discutirei o pensamento de Sara Ahmed sobre as emoções através de duas impressões visualizadas em comentários do Twitter: o racismo reverso e o corpo negro criminali-

\footnotetext{
${ }^{49}$ Tradução de "solitary"; "private" e "injury to become an entitlement, which is then equally available to all others". AHMED, Sara. The cultural politic of emotion, op. cit., p. 29 e 32.

${ }^{50}$ FLAUZINA, Ana Luiza Pinheiro. Democracia genocida. In: FREIXO, Adriano e PINHEIRO-MACHADO, Rosana (orgs.). Brasil em transe: bolsonarismo, nova direita e desdemocratização. Rio de Janeiro: Oficina Raquel, 2019, p. 65.
} 
zado. Posteriormente, alinharei essa discussão com duas charges para pensar como o ódio opera no riso.

No dia 31 de janeiro de 2020, a deputada federal Talíria Petrone (PSOL) postou um comentário em seu Twitter comemorando a absolvição do jovem negro Diego Rodrigues Lima ${ }^{51}$, que foi acusado pelo Ministério Público Federal de incitar discriminação racial em suas redes sociais. O suposto crime aconteceu em Goiânia, em dezembro de 2018. O jovem tornou-se réu em fevereiro de 2019. Segue a postagem da deputada: "Foi a decisão de um juiz federal de Goiás, ao inocentar um jovem negro acusado de racismo reverso nas redes. O juiz na sentença lembrou que não houve "escravidão reversa" e que "a pessoa branca nunca foi discriminada em razão da cor". Vitória!"52

A postagem alcançou 780 compartilhamentos, 5.000 curtidas e 160 comentários. Entre eles, o usuário Roberson Leite abordou a decisão do juiz, enfatizando a existência de racismo reverso e considerando que o racismo no corpo negro é vitimizado simultaneamente. Diz o autor da postagem: “decisão essa escrota! Muitos negros chamam brancos de branquelos, desbotados etc. Todo preconceito deve ser combatido, seja ele qual for. No fundo mesmo, tem muita gente aproveitando a situação e se VITIMIZANDO. Pronto falei!"53

Segundo Ahmed, o ódio implica um sentimento de ameaça do eu por alguma coisa e pressupõe uma retomada do amor no corpo que se sente ameaçado. Esse "eu" é a expressão de um eu coletivo que se marca na pele, reformando os espaços corporais socialmente: "A política do ódio racial envolve atribuir significado a outras pessoas raciais, um processo que podemos descrever como a criação da desesperança. O ódio é o apego negativo a um outro que um deseja expulsar, um apego que é sustentado pela expulsão do outro da proximidade corporal e social".${ }^{54}$

O autor da postagem, ao tomar para o seu corpo o lugar da lesão, defende a dor como algo a ser combatido contra qualquer tipo de raça. Fetichiza a dor. Roberson Leite reordena e, de certo modo, torna ausente a dor do corpo negro especificamente. Esse direcionamento se faz de forma metonímica no uso da palavra "vitimização". Essa palavra carrega um conjunto de memórias da dor negra que desliza a lesão para o corpo branco. O sentir-se ameaçado se constitui na inversão dos lugares políticos que os corpos ocupam.

No dia 27 de novembro de 2019, o rapper Emicida postou em seu Twitter a frase "vidas racistas não importam". ${ }^{55}$ Essa fala gerou uma comoção e obteve 1.3000 .000 comentários, 23.000 compartilhamentos e 82.000 curtidas. Houve os que defenderam a postagem, os que a criticaram, retomando a ideia

\footnotetext{
${ }^{51}$ Ver Tribunal Regional do Estado de Goiás. Processo n. 0003466-46.2019.4.01.3500. Órgão Julgador: 11 Vara de Goiânia. Juiz: João Moreira Pessoa de Azambuja, 27 jan. 2020. Disponível em $<$ https://www.conjur.com.br/dl/clique-aqui-ler-decisao-racismo-reverso.pdf $>$. Acesso em 10 fev. 2020.

52 PETRONE, Talíria. Racismo reverso não existe!. @taliriapetrone, 31 jan. 2020. Disponível em $<$ https://twitter.com/taliriapetrone/status/1223264119370997760>. Acesso em 10 fev. 2020.

${ }^{53}$ LEITE, Roberson. Decisão essa escrota! Muitos negros chamam brancos de branquelos, desbotados. @amorim_adv, 31 jan. 2020. Disponível em <https://twitter.com/amorim_adv/status/1223285863662149633>. Acesso em 10 fev. 2020.

${ }^{54}$ Tradução de "The politics of racial hatred involves attributing racial others with meaning, a process we can describe as 'the making of unlikeness'. Hatred is a negative attachment to an other that one wishes to expel, an attachment that is sustained through the expulsion of the other from bodily and social proximity". AHMED, Sara. The cultural politic of emotion, op. cit., p. 55.

55 EMICIDA. Vidas racistas não importam. @emicida, 27 nov. 2019. Disponível em <https://twitter.com/emicida/status/1199669660721074177>. Acesso em 10 fev. 2020.
} 
neutralizada de que toda a vida importa, bem como os que o xingaram. E aqueles que fizeram uma vinculação entre sua fala e a criminalização do corpo negro. Eis algumas postagens:

1) Os racistas morrem, mas os agressores, homicidas, pedófobos [pedófilos], e afins devem permanecer com sua integridade e liberdade garantida. Entendi, fez todo sentido. 56

2) Então vc pode morrer? Vc é muito racista cara. Para de falar merda cara. Você é um transmissor de ódio. Poderia usar o seu exemplo como um pobre que venceu, mas prefere ser o bravão revoltado. ${ }^{57}$

3) Exemplo de pobre que venceu é Silvio Santos. Desde quando sair da favela pra ganhar dinheiro chupando pica de petista é vencer na vida?58

Nessas postagens, a desqualificação da vida racista é experimentada como um deslizamento de sentidos que toma a fala do cantor como racista e violenta. $\mathrm{Na}$ primeira, ao criar um paralelo entre racismo e bandidos/pedófilos/agressores para se contrapor à fala do cantor, a que pele a autora da postagem está remarcando como criminosa se a pessoa considerada racista é um corpo branco que comete uma ação violenta contra o corpo negro? Na segunda postagem o cantor é acusado de ser racista no mesmo momento em que o desqualifica por evocar a sua origem - "um pobre que venceu na vida". A condição de ser pobre retira o direito de Emicida de poder dizer, considerando que "usar o seu exemplo" pode ser pensado como se adequar aos discursos hegemônicos. Na terceira, há uma intensificação de orientação do corpo negro que passa também a ser impresso como favelado, e esses dois sinais são indicativos de que esse corpo é derrotado, de que o lugar que deve ocupar no mundo não pode ser o mesmo que o do corpo branco. Ódio que se processa como uma ameaça sentida.

Concordo com Ahmed quando diz que "a linguagem e os corpos do ódio operam para criar e desfazer mundos, compostos de outros corpos". O ódio opera nos limites do corpo, implica pensar os efeitos gestados sobre esse corpo odiado. O deputado federal Coronel Tadeu (PSL) quebrou um quadro com uma charge que apontava a violência policial contra os corpos negros. Essa charge fazia parte de uma mostra, em exposição no Congresso Federal em comemoração ao Dia da Consciência Negra e foi desenhada por Carlos Latuff:

\footnotetext{
${ }^{56}$ LIMA, Jessica de. Os racistas morrem, mas os agressores, homicidas, pedófobos, e afins [...]. @jehh_lima, 28 de nov. de 2019. Disponível em <https://twitter.com/Jehh_lima_/status/1200032291793383426>. Acesso em 10 fev. 2020.

57 ARAUJO, Igor. Então vc pode morrer?. @igoraraujojj, 28 nov. 2019. Disponível em $<$ https://twitter.com/igoraraujojj/status/1200002813117583361>. Acesso em 10 fev. 2020.

58 FORTALEZA, Anderson. Exemplo de pobre que venceu é Silvio Santos. @afortaleza, 28 nov. 2019. Disponível em <https://twitter.com/afortaleza/status/1200035106062295040>. Acesso em 10 fev. 2020.
} 


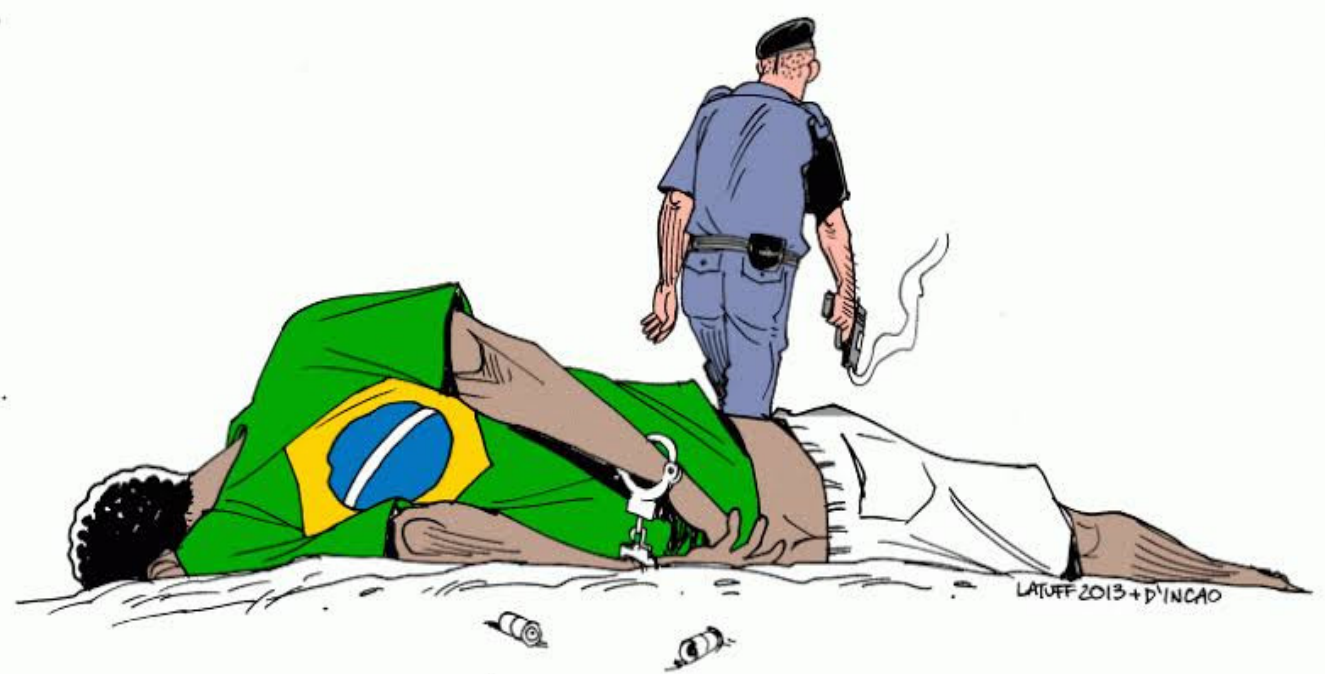

Figura 1. Carlos Latuff, charge, 2019.

O desenho de Latuff mostra o corpo de um jovem negro algemado e assassinado em primeiro plano. Em segundo, a figura de um policial, de costas, saindo do local do crime segurando um revólver na mão direita. Simbolicamente o corpo jovem estava vestindo uma camisa do Brasil e o cano da arma apresentava traços ondulados para indicar que o crime havia ocorrido naquele momento. A proposta do chargista é de apontar um projeto político legalizado pelo estado de genocídio do corpo negro. No dia 21 de novembro de 2019, uma charge parodiando a ilustração de Latuff foi divulgada no Twitter por vários usuários. Essa paródia foi disparada também pela deputada federal Carla Zambelli (PSL/SP), potencializando a disseminação pelo lugar que ela ocupa institucionalmente:

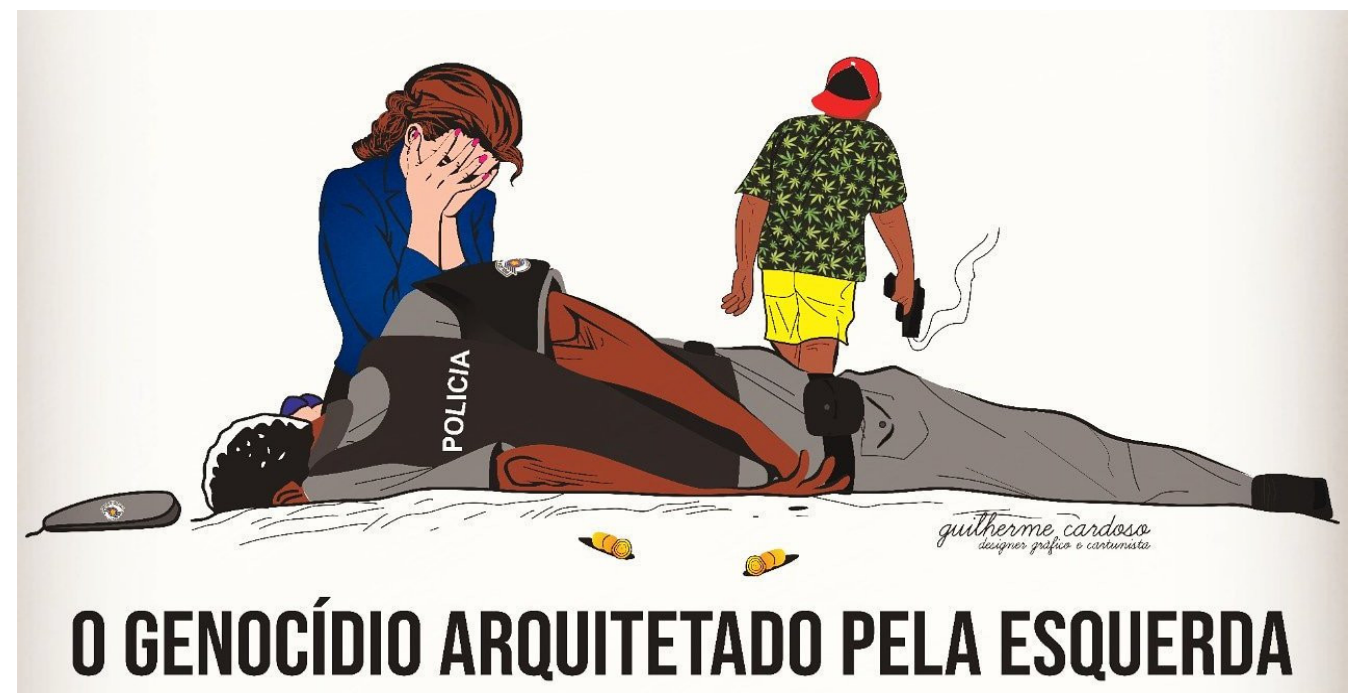

Figura 2. Guilherme Cardoso, charge, 2019. 
Esse desenho reformou o lugar que o corpo negro ocupava no primeiro quadro. De vítima tornou-se vilão. Nessa ilustração, o corpo morto é o corpo do policial que está caído, ao lado de uma mulher de joelhos que chora aquela dor. Em segundo plano, o jovem negro está de costas, saindo com a arma na mão. Todos os dois corpos são negros, a mulher que chora é branca. Esse desenho é um exemplo interessante de como o ódio opera através do humor.

O corpo do policial negro poderia evidenciar como esses corpos estão situados socialmente, apontando para o fato de que há um projeto legalizado pelo Estado que implica a negação do direito à vida de corpos negros. Entretanto, o traje de policial vestindo o corpo morto representa uma ordem que, somada à imagem de uma mulher branca, sugere um branqueamento desse homem. A mulher, que não está contida na charge de Latuff, é colocada na cena como emblema maior de um discurso que vincula os sentimentos e a fragilidade às tradições relacionadas ao corpo feminino. A colocação dessa mulher na narrativa estabelece um diálogo entre a comicidade e as lágrimas para projetar uma experimentação da dor, criando um pacto "co-movente" 59 entre texto e espectador, pois "as lágrimas derramadas opõem-se à análise, e a fria razão é negligenciada em proveito do sentimento" ${ }^{60}$ As lágrimas sinalizam um diálogo entre as matrizes populares do riso e do melodrama como aparatos que oferecem ao espectador uma afetação empática ao policial morto. Como adverte Mariana Baltar, "as lágrimas marcam um lugar, para as narrativas melodramáticas, de profunda comunicação, em uma esfera sensorial e sentimental, com o público. Desse vínculo estabelecido com o público advém a percepção do melodrama como pedagogicamente estratégico no mundo da modernidade". ${ }^{61}$

A encenação dessa mulher branca chorando sustenta a premissa de que é a um corpo branco que é dado o direito de chorar e de se sentir ferido, deslizando esse acontecimento para o corpo morto. Essa articulação redimensiona e embranquece o corpo negro do policial, que, em conjunto com os símbolos históricos do fardamento, remete a um lugar de pertencimento: a dos sujeitos que cuidam da nação.

O jovem negro marcado como criminoso está trajando uma camisa verde de tecido estampado e uma bermuda amarela, remetendo a um tipo de vestimenta utilizada por turistas quando estão no Brasil. Não há em nenhuma parte da roupa o desenho da bandeira nacional; as cores remetem ao Brasil, mas não ao símbolo da ordem. O criminoso que precisa ser expulso está contido na "nação", mas não é interpretado como parte dela. Na acepção de Ahmed, os corpos odiados são visualizados como "corpos fora do lugar". ${ }^{62}$ Por esse motivo, a roupa desenhada do jovem negro se assemelha ao estereótipo do traje do turista.

Desse modo, a pele negra como criminosa nesse desenho torna-se uma marca na superfície e o desenho cria uma impressão - através do comparativo

\footnotetext{
${ }^{59}$ MENDES, Cleise Furtado, op. cit., p. 23.

${ }^{60}$ VINCENT-BUFFAULT, Anne. História das lágrimas. Rio de Janeiro: Paz e Terra, 1988, p. 248.

61 BALTAR, Mariana. Realidade lacrimosa: diálogos entre o universo do documentário e a imaginação melodramática. Tese (Doutorado em Comunicação Social) - UFF, Niterói, 2007, p. 88.

62 Tradução de “bodies out of place”. AHMED, Sara. The cultural politic of emotion, op. cit., p. 2
} 
desse corpo jovem negro (ausente de símbolo da bandeira nacional) com o corpo morto fardado - de inimigo nacional. É uma violação no corpo e sobre o corpo negro que arbitrariamente é deslizado. Assim, esse corpo negro criminalizado é tomado como aquele que ameaça a constituição da ordem - atribuída ao corpo branco. A imagem do perigo negro demarcada por Azevedo ${ }^{63}$ no debate racial que se instaurou na Primeira República é evocada e a memória do passado racista é reacomodada no presente, tornando plausíveis as camadas de violências direcionadas a esse corpo odiado. O desenho, então, satura o objeto (corpo negro) de afetos negativos e sua circulação pelas redes sociais é econômica, constituindo-se como uma potência através da acumulação de valor afetivo.

Portanto, o trabalho das emoções, ancorado em uma historicidade pegajosa, coloca em superfície matrizes emocionais como constituintes de um estatuto narrativo em circulação, contribuindo para um reforço das temáticas e desenhos de corpos risíveis. Esse processo consolida formas de ver, na medida em que reatualiza as produções de sentido históricas.

Acredito que o riso também carrega a teimosia da desobediência, produzindo outras formas de existir como corpo, saturando-o de afetos desordenadores, questionadores e esperançosos. Ao buscar esse desafio de pensar sobre o humor racista, sem retirá-lo de suas corporalidades populares e emocionais, quis alertar para aquilo que o acomoda na ordem, encarcerando corpos risíveis. Descortinar esses trajetos contidos num riso que exclui, destitui a vida do corpo negro em vida e justifica a desigualdade racial é parte constituinte das operações cômicas porque o riso é um território em disputa e um projeto político. Precisamos construir outras maneiras de fazer política, fazer disputar e fazer brincar, mas, para fazer crer possibilidades cômicas através das impossibilidades contidas em uma ordem dominante e que se propõe única, branca e universal, é necessário enxergar a ordem também com os olhos da brincadeira, naquilo que escapa à razão e opera com corpos como mercadorias, pois silenciam a maneira como esses corpos são historicamente saturados de emoções. Assim, olhar para o cômico popular em suas travessias hegemônicas e colonizadoras significa apreender as maneiras como a política perpassa a emoção para com isso termos o direito de gargalhar sem que corpos sejam remarcados pelas dinâmicas da desigualdade racial.

Artigo recebido em 31 de julho de 2020. Aprovado em 20 de outubro de 2020.

${ }^{63}$ AZEVEDO, Célia Maria Marinho de, op. cit. 